\title{
Effects of aerobic and resistance training on the cardiorespiratory fitness of young people with Down Syndrome
}

\section{Efeitos do treinamento aeróbio e resistido na capacidade cardiorrespiratória de jovens com Síndrome de Down}

Bruna Barboza Seron ${ }^{1}$

Everaldo Lambert Modesto

Luiz Cláudio Reeberg Stanganelli²

Emanuel Messias Oliveira de Carvalho

Márcia Greguol ${ }^{2}$

Abstract - The aim of this study was to investigate the effects of 12 weeks of aerobic and resistance training on the maximal and submaximal cardiorespiratory fitness of young people with Down Syndrome (DS). Forty-one individuals of both sexes with Down syndrome (age, $15.51 \pm 2.70 \mathrm{y}$ ) were divided into three groups: CG (control group) with 10 participants; ATG group (aerobic training group) with 16 participants; and RTG (resistance training group) with 15 participants. The training program lasted 12 weeks, with frequency of 3 days a week for ATG and two RTG, and duration of 50 minutes per session. Aerobic training consisted of exercise on a treadmill/bike at intensity between 50 and $70 \%$ of reserve heart rate, while resistance training was composed of nine exercises performed on three sets of 12 maximum repetitions for each exercise. Aerobic and resistance training were not able to increase peak oxygen uptake. However, there was an increase in the maximum ventilation and a decrease of submaximal heart rate only for groups who participated in the training program. Moreover, the aerobic group increased work capacity after training. Training programs led to an improvement in cardiac efficiency during submaximal activities and increased maximum ventilation, which demonstrates a cardiorespiratory improvement

Key words: Cardiorespiratory fitness; Down syndrome; Physical exercise.

Resumo - Objetivou-se investigar o efeito de 12 semanas de treinamento aeróbio e resistido na capacidade cardiorrespiratória máxima e submáxima de jovens com Sindrome de Down (SD).

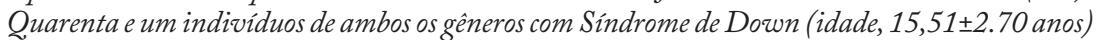
foram divididos em três grupos: GC (grupo controle) com 10 participantes; GTA (grupo treino aeróbio) com 16 participantes; e GTR (grupo treino resistido) com 15 participantes. O programa de treinamento teve duração de 12 semanas, com frequência de 3 dias por semana para o GTA e duas para o GTR, com duração de 50 minutos por sessão. O treino aeróbio era realizado na esteiral bicicleta ergométrica com intensidade entre 50 e $70 \%$ da frequência de reserva, enquanto o treino resistido era composto de nove exercícios que eram realizados em três series de 12 repetiçóes para cada exercício. O treino aeróbio e resistido não foram capazes de aumentar o consumo máximo de oxigênio. Entretanto, houve um aumento na ventilação máxima e diminuição na frequência cardiaca submáxima para os dois grupos que participaram dos programas de treinamento. Além disso, o GTA aumentou a capacidade de trabalho. Os programas de treinamento promoveram uma melhora na eficiência cardiaca durante atividades submáximas e aumento na ventilação máxima, o que demostra uma melhora na capacidade cardiorrespiratória.

Palavras-chave: Aptidão cardiorrespiratória; Exercício físico; Sindrome de Down.

1 Federal University of Santa Catarina. Florianopolis, SC. Brazil.

2 State University of Londrina. Londrina, PR. Brazil.

Received: November 17, 2016 Accepted: July 15, 2017

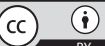
Creative Commom 


\section{INTRODUCTION}

Down syndrome (DS) is the most common chromosomal abnormality in live births, and is the most common chromosomal cause of intellectual disability ${ }^{1}$. The incidence of DS is estimated at approximately one in every 750 live births in Brazil ${ }^{2}$. According to the Ministry of Health ${ }^{3}$, about 270 thousand Brazilians are affected by Down syndrome.

The life expectancy of this population has increased significantly, from only 12 years in 1940 to 60 years in the present day ${ }^{3,4}$. Nevertheless, the average lifespan is still lower than that of the general population. Respiratory diseases, congenital diseases, cardiovascular diseases and cancer $^{3}$ and among the leading causes of death in this population. In this sense, as a form of prevention, especially against cardiovascular diseases, the development of cardiorespiratory fitness is recommended, since this attribute is an important variable of health-related physical fitness and is strongly associated with reduced risk of cardiovascular disease and mortality from all causes ${ }^{5-7}$.

However, children and adolescents with DS have lower cardiorespiratory fitness levels compared to their peers without DS, which can negatively interfere in their health and quality of life $^{8}$. Autonomic dysfunction, reduced ventilatory capacity, and metabolic dysfunction are the three physiological factors that potentially contribute to the low cardiorespiratory fitness levels among people with DS ${ }^{9}$. Moreover, sedentary behavior, associated with some features of this syndrome such as muscular hypotonia, prevalence of heart and pulmonary disease and circulatory system abnormalities, also contribute to this situation ${ }^{10}$. As poor cardiorespiratory fitness at an early age tends to persist in adulthood, it is important to initiate the practice of exercise in this phase of life. Furthermore, the literature indicates reduced maximal and submaximal exercise capacity among people with $\mathrm{DS}^{11}$.

Peak oxygen uptake $\left(\mathrm{VO}_{2}\right.$ peak) is considered the gold standard measure of cardiorespiratory fitness ${ }^{12}$. Regarding the evolution of this variable with training, six studies that examined the influence of exercise on aerobic capacity, specifically evaluating oxygen uptake in young people with $\mathrm{DS}^{13-18}$ were found. Four of these studies found improvements in the $\mathrm{VO}_{2}$ peak levels after training ${ }^{13-16}$, while two others ${ }^{17,18}$ found no positive responses to training in relation to this variable. Moreover, none of the studies found involved resistance training to analyze cardiorespiratory fitness. Therefore, as the results are still contradictory in relation to exercise and the improvement of $\mathrm{VO}_{2}$ peak in this population, further studies are needed to elucidate the subject.

Although cardiovascular control during exercise involves complex mechanisms, it is considered that they can be divided into central and peripheral. The central mechanism is related to the pulse irradiation from the motor cortex to the cardiovascular control center ${ }^{19}$ while the peripheral mechanism is related to the release of metabolites into the active muscle ${ }^{20}$.

Regarding cardiorespiratory fitness and submaximal exercise, only one study involving children with DS that analyzed training adaptations for this variable was found. This research was a case study in which a 
10.5-year-old girl with DS performed combined training (resistance and aerobic of moderate intensity) for 6 weeks with frequency of 5-6 days a week and each exercise session lasted from 30 to 60 minutes. At the end of intervention, the authors ${ }^{14}$ found a reduction in heart rate in all stages of submaximal exercise. Other studies ${ }^{11,21}$, involving adults with DS found improvements in motion economy, expressed by reduction of oxygen uptake during submaximal exercise.

Considering the importance of maximal and submaximal cardiorespiratory fitness for the health of young people with DS, in addition to the small number of studies on this topic, this study aimed to determine the effects of 12 weeks of aerobic and resistance training on the maximal and submaximal cardiorespiratory fitness of young people with DS.

\section{METHODOLOGICAL PROCEDURES}

\section{Participants}

The study included 41 individuals of both sexes with Down syndrome aged 12- 20 years, who had been medically cleared to practice physical exercises. Individuals with cardiac or orthopedic impairments; those using medications that altered heart rate or presented severe or profound intellectual disability that impaired the understanding and / or performance of procedures were excluded from the study. Participants were recruited from three institutions for people with intellectual disabilities in Londrina / PR / Brazil. After being informed about the research contents, participants and their legal guardians signed the consent form. The study was approved by the Ethics Committee on Research with Human Beings of the State University of Londrina, protocol number 93.680/2012.

In accordance with their availability to attend the exercise program, participants were divided for convenience into three groups namely CG (control group) with 10 participants (six girls and four boys); ATG (aerobic training group) with 16 participants (five girls and 11 boys); and RTG (resistance training group) with 15 participants (five girls and 10 boys). Subjects who participated in the control group reported that they practiced no physical activity on a regular basis and were instructed to continue their usual activities.

\section{Maximal and submaximal cardiorespiratory evaluation}

Cardiorespiratory fitness (peak oxygen uptake - $\mathrm{VO}_{2}$ peak; maximum ventilation - VEmax and maximum heart rate - HRmax) was assessed using a maximal exercise test with validated protocol for people with Down Syndrome $^{22}$. This test was performed on a treadmill and consisted of an initial speed of $4 \mathrm{~km} / \mathrm{h}$ with $0 \%$ slope for two minutes, followed by $2.5 \%$ increase in the slope every two minutes until maximum height of $12.5 \%$. From this point, the speed was increased $1.6 \mathrm{~km} / \mathrm{h}$ every minute until exhaustion. Data acquired during the test were filtered every $10 \mathrm{~s}$ for analysis. The valid $\mathrm{VO}_{2}$ peak was considered the highest value obtained during the final stage of the exercise with respiratory exchange ratio (RER) greater than 1.0. 
To determine the submaximal cardiorespiratory fitness, data from the first three stages of the maximal exercise test (which had duration of two minutes each) were analyzed, with average values of indicators (heart rate, oxygen uptake and ventilation) obtained in the last 30s of each stage being considered for the analysis.

The test was performed on a treadmill (INBRAMED, model 10.200) and a portable ergo-spirometer (Cosmed k4b2 , Italy) was used. Familiarization session was held on the use of the treadmill and the mask.

\section{Training Programs}

Aerobic and resistance training programs consisted of 12 weeks of exercise sessions, each lasting for 50 minutes.

Aerobic training was performed on a treadmill and stationary bike (15 minutes each) three times a week at intensity between 50 and 70\% of HRreserve for 30 minutes, preceded by 10 minute warm-up (joint and stretching) and followed by 10 minutes of recovery (stretching). Intensity was monitored through the use of Polar FT2 heart rate monitor. HRmax used to calculate the HRreserve was obtained in the maximal exercise test.

Resistance training was composed of nine exercises performed in three sets of 12 repetitions, with an interval of one minute between sets and three minutes between exercises. The following series of exercises was proposed: bench press machine, leg extension, front pull-ups, biceps curls, standing leg curl with ankle weights, triceps curls, calf raise with ankle weights, front lifting with dumbbells and abdominals. The first two sessions served as adaptations to exercises with light loads and, thereafter, the load used was estimated by observing the ability of participants to perform 12 exercise repetitions. The load progression was spontaneous, being increased with the individual's ability to perform three sets of 12 complete repetitions ${ }^{12}$.

\section{Statistical Analyses}

Data were initially examined using descriptive statistics, presented as mean and standard deviation. Data normality was verified using the Shapiro-Wilk test. The paired student's $t$ test was used for intra-group comparison between pre- and post-training cardiorespiratory values. As for the comparison in a single moment between groups, the one-way ANOVA with Tukey's post hoc was used. Effect size (ES) was calculated using Psychometrica software, and its interpretation was performed using Cohen's recommendations ${ }^{23}$. Data were processed in the Statistical Package for the Social Sciences version 18.0, and in all cases, the significance level was $\mathrm{P}<0.05$.

\section{RESULTS}

As presented in Table 1, no differences were observed among groups regarding age or body weight. However, the control group (CG) had significantly lower height than the other groups, and the resistance training group (RTG) presented lower BMI than CG and ATG. 
Table 1.General characteristics of participants

\begin{tabular}{lccc}
\hline & $\begin{array}{c}\text { ATG } \\
(\mathrm{n}=16)\end{array}$ & $\begin{array}{c}\text { RTG } \\
(\mathrm{n}=15)\end{array}$ & $\begin{array}{c}\text { CG } \\
(\mathrm{n}=10)\end{array}$ \\
\hline Sex(male/female) & $11 / 5$ & $10 / 5$ & $4 / 6$ \\
Age (years) & $15.7 \pm 2.7$ & $16 \pm 2.8$ & $14.4 \pm 2.5$ \\
Body weight $(\mathrm{kg})$ & $61.5 \pm 10.8$ & $52.7 \pm 10.0$ & $54.7 \pm 11.8$ \\
Height $(\mathrm{cm})$ & $151.0 \pm 8.4$ & $150.4 \pm 7.0$ & $140.0 \pm 9.1^{*}$ \\
BMl $\left(\mathrm{kg} / \mathrm{m}^{2}\right)$ & $27.0 \pm 4.4$ & $23.3 \pm 4.3^{*}$ & $27.6 \pm 3.8$ \\
\hline
\end{tabular}

*Significantly different from the other groups $(p<0.05)$

The peak oxygen uptake was homogeneous at pre-training for all groups, but for post-training $\mathrm{VO}_{2}$ peak, CG showed significantly lower values than the other two groups. As can be observed in Table 2, training did not improve the values of this variable, on the other hand, the group not submitted to training demonstrated significantly reduced $\mathrm{VO}_{2}$ peak values.

There was an increase in maximum ventilation for groups that participated in the training program, while values for the control group did not change significantly between the two moments. However, it is worth mentioning that the control group already had lower pre-training maximal ventilation compared to values obtained for the aerobic group, and at posttraining, these values were significantly lower than the other two groups.

TTT (total test time) for ATG significantly increased while the other two groups showed no differences between pre-and post-training conditions. In addition, for $\mathrm{CG}$, the total test time at post-training condition was significantly lower than that of the aerobic and resistance group.

For the analysis of the submaximal capacity of individuals, the $\mathrm{VO}_{2}$ (oxygen uptake), HR (heart rate) and VE (ventilation) values at the $1^{\text {st }}$ ( $4 \mathrm{~km} / \mathrm{h}$ with $0 \%$ slope), $2^{\text {nd }}(4 \mathrm{~km} / \mathrm{h}$ with $2.5 \%$ slope $)$ and $3^{\text {rd }}(4 \mathrm{~km} / \mathrm{h}$ with $5.0 \%$ slope) stages of the maximal test were considered.

Table 3 shows a reduction in $\mathrm{VO}_{2}$ of all groups in all submaximal stages, except for the $1^{\text {st }}$ stage for the resistance group. The ventilation values in submaximal stages were significantly lower for the aerobic and control groups. The resistance group presented no significant changes in this variable between the two moments. The heart rate of the training groups was significantly lower at all submaximal stages; however the control group showed no significant difference in this variable at any time.

Table 2. Maximal cardiorespiratory fitness measurements at pre- and post-training conditions described as mean \pm standard deviation.

\begin{tabular}{|c|c|c|c|c|c|c|c|c|}
\hline Variables & Aerobic $\mathrm{Tr}$ & ning Group & Resistance Tr & aining Group & Cont & I Group & Effec & Size \\
\hline & Pre & Post (ES) & Pre & Post (ES) & Pre & Post (ES) & TG-CG & TG-CG \\
\hline $\begin{array}{l}\text { V0 }{ }_{2} \text { peak } \\
(\mathrm{ml} / \mathrm{kg} / \mathrm{min})\end{array}$ & $30.54 \pm 6.26$ & $\begin{array}{c}30.01 \pm 5.88 \\
(0.087)\end{array}$ & $31.69 \pm 5.97$ & $\begin{array}{c}30.49 \pm 5.90 \\
(0.203)\end{array}$ & $28.05 \pm 3.86$ & $\begin{array}{c}21.25 \pm 4.3^{*} \dagger \\
(1.641)\end{array}$ & 3.947 & 3.449 \\
\hline $\begin{array}{l}\operatorname{HRmax} \\
\text { (bpm) }\end{array}$ & $180 \pm 9$ & $\begin{array}{c}184 \pm 8 \\
(-0.497)\end{array}$ & $179 \pm 18.39$ & $\begin{array}{c}181 \pm 11.84 \\
(-0.109)\end{array}$ & $187 \pm 12.59$ & $\begin{array}{c}182 \pm 17.75 \\
(0.275)\end{array}$ & 2.293 & 1.539 \\
\hline $\begin{array}{l}\text { VE } \\
(\mathrm{I} / \mathrm{min} / \mathrm{m})\end{array}$ & $66.04 \pm 18.11$ & $\begin{array}{c}78.09 \pm 20.6^{*} \\
(0.615)\end{array}$ & $57.54 \pm 13.13$ & $\begin{array}{c}70.20 \pm 17.59^{*} \\
(0.79)\end{array}$ & $50.78 \pm 12.55 \ddagger$ & $\begin{array}{c}46.03 \pm 9.9 \dagger \\
(-0.403)\end{array}$ & 3.433 & 3.484 \\
\hline $\begin{array}{l}\text { TTT } \\
\text { (s) }\end{array}$ & $815.9 \pm 139.4$ & $\begin{array}{c}901.5 \pm 61.0^{*} \\
(-0.49)\end{array}$ & $853.80 \pm 119.5$ & $\begin{array}{c}898.26 \pm 81.3 \\
(-0.413)\end{array}$ & $755.90 \pm 170.7$ & $\begin{array}{c}4722.90 \pm 118.4 \dagger \\
(0.225)\end{array}$ & 3.005 & 1.924 \\
\hline
\end{tabular}

${ }^{*} p<0.05$ - significant difference when pre-and post-training conditions were compared. $\dagger p<0.05$ - significant difference with the other groups at a single moment. $\ddagger p<0.05$ - significant difference with ATG. 
Table 3. Submaximal cardiorespiratory fitness measurements at pre- and post-training conditions described as mean \pm standard deviation

\begin{tabular}{|c|c|c|c|c|c|c|c|c|}
\hline \multirow[t]{2}{*}{ Variables } & \multicolumn{2}{|c|}{ Aerobic Training Group } & \multicolumn{2}{|c|}{ Resistance Training Group } & \multicolumn{2}{|c|}{ Control Group } & \multicolumn{2}{|c|}{ EffectSize } \\
\hline & Pre & Post (ES) & Pre & Post (ES) & Pre & Post (ES) & ATG-CG & RTG-CG \\
\hline \multicolumn{9}{|l|}{$\begin{array}{l}\mathrm{VO}_{2} \\
(\mathrm{ml} / \mathrm{kg} / \mathrm{min})\end{array}$} \\
\hline $\begin{array}{l}4.0 \mathrm{~km} / \mathrm{h}\left(1^{\mathrm{st}}\right. \\
\text { stage) }\end{array}$ & $19.06 \pm 5.29$ & $\begin{array}{c}12.9 \pm 3.09^{*} \\
(1.43)\end{array}$ & $17.64 \pm 3.22$ & $\begin{array}{c}16.02 \pm 3.30 \\
(0.496)\end{array}$ & $16.62 \pm 3.75$ & $\begin{array}{c}10.60 \pm 5.48^{*} \\
(1.226)\end{array}$ & -0.029 & 1.26 \\
\hline $\begin{array}{l}2.5 \% \\
\left(2^{\text {nd }} \text { stage }\right)\end{array}$ & $20.08 \pm 4.17$ & $\begin{array}{c}14.50 \pm 2.4^{\star} \\
(1.618)\end{array}$ & $19.27 \pm 3.39$ & $\begin{array}{c}17.10 \pm 2.99^{*} \\
(0.673)\end{array}$ & $18.04 \pm 3.44$ & $\begin{array}{c}11.36 \pm 5.15^{\star} \\
(1.456)\end{array}$ & 0.278 & 1.305 \\
\hline $\begin{array}{l}5.0 \% \\
\left(3^{\text {rd }} \text { stage }\right)\end{array}$ & $20.64 \pm 5.37$ & $\begin{array}{c}15.74 \pm 3.26 \\
(1.084)\end{array}$ & $19.86 \pm 3.78$ & $\begin{array}{c}17.70 \pm 2.59^{*} \\
(0.6)\end{array}$ & $18.90 \pm 3.04$ & $\begin{array}{c}12.23 \pm 3.12^{*} \dagger \\
(2.16)\end{array}$ & 0.377 & 1.273 \\
\hline \multicolumn{9}{|l|}{$\mathrm{HR}(\mathrm{bpm})$} \\
\hline $\begin{array}{l}4.0 \mathrm{~km} / \mathrm{h}\left(1^{\mathrm{st}}\right. \\
\text { stage) }\end{array}$ & $135 \pm 19$ & $\begin{array}{c}106 \pm 13^{*} \\
(1.698)\end{array}$ & $119 \pm 10$ & $\begin{array}{c}112 \pm 11^{*} \\
(0.692)\end{array}$ & $131 \pm 18$ & $\begin{array}{c}131 \pm 18 \dagger \\
(0.039)\end{array}$ & -1.538 & -0.499 \\
\hline $\begin{array}{l}2.5 \% \\
\left(2^{\text {nd }} \text { stage }\right)\end{array}$ & $133 \pm 21$ & $\begin{array}{c}112 \pm 14^{*} \\
(1.097)\end{array}$ & $125 \pm 11$ & $\begin{array}{c}112 \pm 12^{*} \\
(1.103)\end{array}$ & $136 \pm 17$ & $\begin{array}{c}131 \pm 21 \dagger \\
(0.247)\end{array}$ & -0.807 & -0.573 \\
\hline $\begin{array}{l}5.0 \%\left(3^{\text {rd }}\right. \\
\text { stage) }\end{array}$ & $143 \pm 17$ & $\begin{array}{c}116 \pm 13^{*} \\
(1.648)\end{array}$ & $132 \pm 12$ & $\begin{array}{c}118 \pm 10^{*} \\
(1.212)\end{array}$ & $141 \pm 13$ & $\begin{array}{c}139 \pm 18 \dagger \\
(0.15)\end{array}$ & -1.582 & -0.954 \\
\hline \multicolumn{9}{|l|}{$\begin{array}{l}\text { VE } \\
(\mathrm{I} / \mathrm{min} / \mathrm{m})\end{array}$} \\
\hline $\begin{array}{l}4.0 \mathrm{~km} / \mathrm{h} \\
\left(1^{\text {st }} \text { stage }\right)\end{array}$ & $31.15 \pm 9.32$ & $\begin{array}{c}23.66 \pm 8.19^{*} \\
(0.853)\end{array}$ & $24.83 \pm 5.41$ & $\begin{array}{c}24.45 \pm 4.69 \\
(0.075)\end{array}$ & $24.39 \pm 8.69$ & $\begin{array}{c}19.45 \pm 8.71^{*} \\
(0.568)\end{array}$ & -0.277 & 0.648 \\
\hline $\begin{array}{l}2.5 \% \\
\left(2^{\text {nd }} \text { stage }\right)\end{array}$ & $35.21 \pm 11.38$ & $\begin{array}{c}25.74 \pm 4.74^{*} \\
(1.012)\end{array}$ & $28.02 \pm 6.24$ & $\begin{array}{c}26.88 \pm 4.47 \\
(0.206)\end{array}$ & $27.56 \pm 8.19$ & $\begin{array}{l}21.18 \pm 7.79^{*} \\
\quad(0.797)\end{array}$ & -0.297 & 0.728 \\
\hline $\begin{array}{l}5.0 \% \\
\left(3^{\text {rd }} \text { stage }\right)\end{array}$ & $36.78 \pm 10.59$ & $\begin{array}{c}29.02 \pm 6.60^{*} \\
(0.863)\end{array}$ & $30.00 \pm 7.25$ & $\begin{array}{c}28.08 \pm 4.35 \\
(0.198)\end{array}$ & $31.72 \pm 9.16$ & $\begin{array}{c}24.27 \pm 6.88^{*} \\
(0.843)\end{array}$ & -0.03 & 0.675 \\
\hline
\end{tabular}

${ }^{*} p<0.05$ - significant difference when pre-and post-training conditions were compared. $\uparrow p<0.05$ - significant difference with the other groups at a single moment.

\section{DISCUSSION}

Concerning maximal cardiorespiratory fitness, the results of this study showed that training (aerobic or resistance) was not able to improve the $\mathrm{VO}_{2}$ peak levels of participants. Similar results were found in studies by Varela et al. ${ }^{18}$ and Millar et al. ${ }^{17}$ who performed aerobic training for 16 and 10 weeks respectively.

Tsimaras et al. ${ }^{24}$ suggested that the lack of improvement observed in $\mathrm{VO}_{2}$ peak may have been due to inadequate intensity tracking during exercises. However, in the present study, the intensity of the aerobic training group was controlled by heart rate monitors, and participants maintained the established intensity throughout training. The resistance training group, despite the increased load being subjective, was constantly controlled and the load adjusted to ensure that individuals realized a maximum of 12 repetitions.

Another fact suggested as being responsible for the low $\mathrm{VO}_{2}$ peak values is the low HRmax (about 30\% less than expected) observed in individuals with $\mathrm{DS}^{25}$. However, it was not observed in the participants of the present study, as in the two assessments performed, HRmax was above $90 \%$ of predicted HRmax. Furthermore, no significant differences in HRmax were observed between evaluations, suggesting that participants with DS produced valid maximal efforts in both tests. 
Two studies previously conducted showed an increase in $\mathrm{VO}_{2}$ peak after the training program ${ }^{13,16}$. However, it is necessary to interpret the results with caution, since the interventions performed in these studies were different. Casajus et al. ${ }^{13}$ obtained an increase in $\mathrm{VO}_{2}$ peak (pre 32.5 $\mathrm{ml} / \mathrm{kg} / \mathrm{min} x$ post $42.0 \mathrm{ml} / \mathrm{kg} / \mathrm{min}$ ) after 30 weeks of training, with a frequency of twice a week, for one hour per session. On one day a week, young people practiced athletics, basketball, volleyball, soccer or handball and on the other day, they practiced swimming. The intensity reported by the authors was 60 to $75 \%$ of $\mathrm{VO}_{2}$ peak. Savucu ${ }^{16}$ also found improvements in $\mathrm{VO}_{2}$ peak (pre $20.91 \mathrm{ml} / \mathrm{kg} / \min \mathrm{x}$ post $22.35 \mathrm{ml} / \mathrm{kg} / \mathrm{min}$ ) after 12 weeks of aerobic training, which consisted of a 30-minute walk on an athletic track without specific intensity. The method evaluated in this study, however, was indirect (16 m shuttle-run).

Despite these two studies, researchers have claimed that training, whether aerobic or resistance, causes little or no change in $\mathrm{VO}_{2}$ peak in young people with DS. Still on the cardiorespiratory adaptations to training, the findings of this study showed a significant increase in pulmonary ventilation (VE) for young people who participated in the training program, whether aerobic or resistance. The increased maximum pulmonary ventilation in this population is interesting because due to the restricted size of airways, the small nasal passage and large tongue can obstruct breathing during exercise ${ }^{11}$.

One variable that could be regarded as the work capacity of an individual in the test is the total test time (TTT), which is the time the individual continued exercise until exhaustion. In this case, TTT of the second evaluation was significantly higher $(\mathrm{p}<0.05)$ in subjects who participated in the aerobic training program (mean increase of 1.26 minutes). The other two groups showed no significant changes in this variable.

Similarly to the present study, although no improvements were observed in $\mathrm{VO}_{2}$ peak, other studies have found an increase in work capacity translated by increased time to exhaustion. Millar et al. ${ }^{17}$ found an average increase of 1.06 minutes whereas Varela et al. ${ }^{18}$ found an average increase of 3.4 minutes.

Dodd and Shields ${ }^{10}$ argued that this improvement was probably related to the change from a sedentary lifestyle to participation in a program that includes endurance activities. Such positive adaptations can significantly affect the person's ability to perform activities of daily living and to integrate in the community, thus bringing general benefits to life.

The main finding of this study regarding the training adaptations to submaximal exercise was a significant reduction in heart rate in the intermediate stages of the maximal graded test. This reduction was only observed in individuals who participated in the training program (aerobic or resistance) and not in the control group. This finding suggests that the heart had become more efficient due to training, as it performed less work at the same intensity rate.

According to Brum et al. ${ }^{20}$, the lower heart rate during progressive effort exercise is a result of changes in autonomic balance after cardiac 
training associated with lower vagal withdrawal and reduced intensity of the sympathetic activity. This adaptation is extremely important, since, according to Seccarecia and Menotti ${ }^{26}$, there is a direct relationship between submaximal heart rate or resting heart rate and the risk of developing cardiovascular diseases, indicating that individuals with lower resting heart rate or lower heart rate during submaximal exercise are less likely of developing heart diseases. This is especially beneficial for people with DS, since $40-50 \%$ of this population have conditions associated with the cardiovascular system ${ }^{27}$.

Another significant change observed in the second evaluation was the reduction in oxygen uptake. According to Denadai ${ }^{28}$, the oxygen cost $\left(\mathrm{VO}_{2}\right)$ for a given submaximal activity is called motion economy (ME). In this context, good $\mathrm{ME}$ is manifested by lower fractional utilization of $\mathrm{VO}_{2}$ peak at a given speed, and consequently, a reduction in the use of glycogen and less dependence on the $\mathrm{O} 2$-independent metabolism, which leads to attenuated metabolic acidosis. However, motion economy was observed in all groups, including the group which did not participate in the training program. Therefore, it is not possible to infer that the observed ME was a result of training.

Pateet al. ${ }^{29}$ demonstrated a positive relationship of $\mathrm{HR}$ and pulmonary ventilation (VE) with submaximal VO2, stating that better ME is associated with lower HR and VE. In this sense, the resistance training group presented reduction only in $\mathrm{HR}$, while the control group only demonstrated reduction in $\mathrm{VE}$ and the aerobic group demonstrated a reduction in both variables. The only study found that has investigated the motion economy in people with DS was that of de Mendonça et al. ${ }^{21}$. The authors studied the effects of 12 weeks of combined training on 13 adults with DS and observed improvements in the ME of these adults.

Some authors support the idea that improvements in motion economy can cause gains in work capacity, even without changes in $\mathrm{VO}_{2} \mathrm{peak}^{30}$. However, Mendonça et al. ${ }^{21}$ argue that the improvement in work capacity may arise from the interaction between motion economy and $\mathrm{VO}_{2}$ peak.

In the present study, the only group that presented significant improvements in work capacity, represented by time to exhaustion in the treadmill test, was the aerobic training group; however, no changes were observed in $\mathrm{VO}_{2}$ peak. Nevertheless, this group did show improvement in $\mathrm{ME}$ and reductions in $\mathrm{HR}$ and VE. The control group presented reduced work capacity, despite improvements in ME; in this group, however, no changes were observed in submaximal HRand a reduction was also observed in $\mathrm{VO}_{2}$ peak. On the other hand, the resistance group, despite presenting significantly reduced HR during submaximal exercise and improvements in $\mathrm{ME}$, showed no reduction in VE, which may have contributed to the lack of improvement in work capacity. Therefore, from the results obtained in this study, it is suggested that work capacity may be related to three variables (improvement in $\mathrm{ME}$ and reduction in $\mathrm{HR}$ and $\mathrm{VE}$ ), compensating for the lack of improvement in $\mathrm{VO}_{2}$ peak. 
Despite these findings, there are some limitations in the present study. First, the low number of individuals in each group may have limited the statistical analysis together with the sample selection, and the non-random division of groups due to the difficulties of participants in adhering to the training protocol. Another limitation refers to the volume of the proposed training intervention, since the number of weekly sessions and the duration of training sessions may not have been sufficient to generate significant impacts on cardiorespiratory fitness. Notwithstanding, data collected here provide information to health professionals, giving them a greater understanding on the cardiorespiratory adaptations of young people with DS to physical exercises, which could help guide their actions.

\section{CONCLUSION}

The training programs led to an improvement in cardiac efficiency during submaximal activities and increased maximum ventilation, which demonstrates a cardiorespiratory improvement. In particular, the aerobic training increased work capacity. Young people with DS who did not perform physical exercise presented worse peak oxygen uptake indicators, whereas the training groups presented no changes for this variable.

Thus, it confirms the importance of exercise programs for young people with DS and the awareness among young people and their parents about the dangers of sedentary lifestyle. Programs with different training volumes and intensities should be proposed with the aim of achieving positive responses for variables that were not responsive to the training program proposed in this study.

\section{REFERENCES}

1. Frid C, Drott P, Lundell B, Rasmussen F, Anneren G. Mortality in Down's syndrome in relation to congenital malformations. J Intellect Disabil Res 1999;43 (Pt 3):234-41.

2. Lana-Elola E, Watson-Scales SD, Fisher EM, Tybulewicz VL. Down syndrome: searching for the genetic culprits. Dis Model Mech 2011;4(5):586-95.

3. Bittles AH, Bower C, Hussain R, Glasson EJ. The four ages of Down syndrome. Eur J Public Health 2007;17(2):221-5.

4. Glasson EJ, Sullivan SG, Hussain R, Petterson BA, Montgomery PD, Bittles AH. The changing survival profile of people with Down's syndrome: implications for genetic counselling. Clin Genet 2002;62(5):390-3.

5. Katzmarzyk PT, Church TS, Blair SN. Cardiorespiratory fitness attenuates the effects of the metabolic syndrome on all-cause and cardiovascular disease mortality in men. Arch Intern Med 2004; 164(10):1092-7.

6. Kodama S, Saito K, Tanaka S, Maki M, Yachi Y, Asumi M, et al. Cardiorespiratory fitness as a quantitative predictor of all-cause mortality and cardiovascular events in healthy men and women: a meta-analysis. JAMA 2009;301(19):2024-35.

7. Sui X, LaMonte MJ, Laditka JN, Hardin JW, Chase N, Hooker SP, et al. Cardiorespiratory fitness and adiposity as mortality predictors in older adults. JAMA 2007;298(21):2507-16.

8. Gonzalez-Aguero A, Vicente-Rodriguez G, Moreno LA, Guerra-Balic M, Ara I, Casajus JA. Health-related physical fitness in children and adolescents with Down syndrome and response to training. Scand J Med Sci Sports 2010;20(5):716-24. 
9. Pitetti K, Baynard T, Agiovlasitis S. Children and adolescents with Down syndrome, physical fitness and physical activity. J Sport Health Sci 2013; (2) 47-57.

10. Dodd KJ, Shields N. A systematic review of the outcomes of cardiovascular exercise programs for people with Down syndrome. Arch Phys Med Rehabil 2005;86(10):2051-8.

11. Mendonca GV, Pereira FD, Fernhall B. Reduced exercise capacity in persons with Down syndrome: cause, effect, and management. Ther Clin Risk Manag 2010;(6):601-10.

12. American College of Sports Medicine. ACSM's Guidelines for Exercise Testing and Prescription. 8th ed ed. Baltimore; 2009.

13. Casajus J, Pueyo D, Vicente-Rodríguez G, González-Agüero A. Mejoras de la condición cardiorrespiratoria en jóvenes con síndrome de Down mediante entrenamiento aeróbico: estudio longitudinal. Apunts Med Esport 2012;47(174):49-54.

14. Lewis CL, Fragala-Pinkham MA. Effects of aerobic conditioning and strength training on a child with Down syndrome: a case study. Pediatr Phys Ther 2005;17(1):30-6.

15. Mosso C, Santander P, Pettinelli R, Valdés G, Celis B, EspejoS, et al. Evaluación de una intervención en actividad física en niños con síndrome de Down. Rev Chil Pediatr 2011;82(4):2311-318.

16. Savucu Y. Influence of 12-Week Training on Aerobic Capacity and Respiratory Functions of Adolescents with down Syndrome. World Appl Sci J 2010;11(10):1292-6.

17. Millar AL, Fernhall B, Burkett LN. Effects of aerobic training in adolescents with Down syndrome. Med Sci Sports Exerc 1993;25(2):270-4.

18. Varela AM, Sardinha LB, Pitetti KH. Effects of an aerobic rowing training regimen in young adults with Down syndrome. Am J Ment Retard 2001;106(2):135-44.

19. Seals DR, Washburn RA, Hanson PG, Painter PL, Nagle FJ.Increased cardiovascular response to static contraction of larger muscle groups. J Appl Physiol 1983;(54):434-7.

20. Brum PC, Forjaz CLM, Tinucci T, Negrão E. Adaptações agudas e crônicas do exercício físico no sistema cardiovascular. Rev Paul Educ Fís 2004;(18):31-21.

21. Mendonca GV, Pereira FD, Fernhall B. Effects of combined aerobic and resistance exercise training in adults with and without Down syndrome. Arch Phys Med Rehabil 2011;92(1):37-45.

22. Fernhall B, Pitetti KH, Rimmer JH, McCubbin JA, Rintala P, Millar AL, et al. Cardiorespiratory capacity of individuals with mental retardation including Down syndrome. Med Sci Sports Exerc 1996;28(3):366-71.

23. Cohen J. Statistical power analysis for the behavioral sciences. 2nd ed. New Jersey: Lawrence Erlbaum; 1988.

24. Tsimaras V, Giagazoglou P, Fotiadou E, Christoulas K, Angelopoulou N. Jog-walk training in cardiorespiratory fitness of adults with Down syndrome. Percept Mot Skills 2003;96(3 Pt 2):1239-51.

25. Baynard T, Pitetti KH, Guerra M, Unnithan VB, Fernhall B. Age-related changes in aerobic capacity in individuals with mental retardation: a 20-yr review. Med Sci Sports Exerc 2008;40(11):1984-9.

26. Seccareccia F, Menotti A. Physical activity, physical fitness and mortality in a sample of middle aged men followed-up 25 years. J Sports Med Phys Fitness 1992;32(2):206-13.

27. Diretrizes de Atenção à Pessoa com Síndrome de Down [databaseonthe Internet]2012. Available from: http://portal.saude.gov.br/portal/arquivos/pdf/diretrizes_cuidados_sindrome_down.pdf.

28. Denadai SD. Aspectos Fisiológicos Relacionados com a Economia de Movimento. Rev Bras Ativ Fís Saúde 1996;1(3):59-73.

29. Pate RR, Macera CA, Bailey SP, Bartoli WP, Powell KE. Physiological, anthropometric, and training correlates of running economy. Med Sci Sports Exerc 1992;24(10):1128-33.

30. McCann DJ, Higginson BK. Training to maximize economy of motion in running gait. Curr Sports Med Rep 2008;7(3):158-62.

\section{CORRESPONDING AUTHOR}

Bruna Barboza Seron Rodovia Amaro Antônio Vieira, 2651;

CEP:88034101 - Florianópolis/

Santa Catarina

Email: bruna.seron@ufsc.br 